\title{
Effect of ultrasound on protoscoleces of Echinococcus granulosus in vitro and in vivo
}

\author{
A.A. Ali ${ }^{\circ}$ and B.B. Ramadhan \\ Department of Biology, College of Education for Pure Sciences, University of Mosul, Mosul, Iraq
}

Article information

Article history:

Received April 09, 2020

Accepted May 06, 2020

Available online July 1, 2021

\section{Keywords:}

Echinococcus granulosus

Ultrasound

Delayed-type hypersensitivity

Correspondence:

A.A. Ali

dr.asmaa_abdulaziz@uomosul.edu.iq

\begin{abstract}
The current study was designed to investigate the effect of ultrasound on the protoscoleces of Echinococcus granulosus by enforcing steady numeral of frequencies during a certain interval (20000 pulse/s) $\left(1.8 \mathrm{w} / \mathrm{cm}^{2}\right)$, using exposure time 30,20,15,12,10 and $5 \mathrm{~s}$, individually and respectively. Consequently, six albino mice groups were immunized against cystic echinococcosis, which injected with exposed protoscoleces, to acquire specific cell-mediated immunity, called delayed type-hypersensitivity (DTH) which assessment by measurement the foot pad density. The results displayed significant excess $(\mathrm{P} \leq 0.001)$ of DTH by increase of foot pad thickness in injected groups. The results showed maximum thickness of $1.54 \mathrm{~mm}, 1.4 \mathrm{~mm}, 0.9 \mathrm{~mm}$. after $3 \mathrm{~h}, 24 \mathrm{~h}$, and $48 \mathrm{~h}$ post injection, respectively, that compared with the thickness of control group 1.072, 0.638, $0.328 \mathrm{~mm}$, respectively, during five months of experiment. The present research exhibited the action of ultrasonication technique on the viability of Echinococcus granulosus protoscoleces in vitro. Conclusion, Ultrasound frequencies used in the present study could be have consequential impact on the cellular immunity in albino mice.
\end{abstract}

DOI: 10.33899/ijvs.2021.126906.1410, (C2021, College of Veterinary Medicine, University of Mosul.

This is an open access article under the CC BY 4.0 license (http://creativecommons.org/licenses/by/4.0/).

\section{Introduction}

Cystic echinococcosis is chronic and complicated disease in humans and animals, and it leads to many health problems and economic losses in developing countries resulting from the costs of diagnosis, medical treatment and resulting disabilities is some cases in human $(1,2)$. Cystic echinococcosis is endemic in the Mediterranean, Middle East, eastern European, Eastern Africa, Australia, and China (3). The life cycle of the Echinococcus granulosus includes two hosts, definitive host includes carnivores such as the canidae and felidae families such as dogs, foxes and hyenas, and intermediate host, includes herbivores - such as -sheep, buffalo, camels, pigs, and rodents and human as accidental host $(4,5)$. Diagnosis of cystic echinococcosis is based on imaging techniques, like ultrasound as a major tool for classification of hydatid cysts (6). Whereas serological methods were used for confirmation only (7). Ultrasound is a physical and therapeutic method as non- ionizing radiation in the form of mechanical sound waves to the tissues to raise the temperature. Since 1970 ultrasound has been used to detect a variety of diseases. High intensity focused ultrasound (HIFU) was also used initially to treat cancer like prostate tumors, brain diseases such as Parkinson's disease, treatment of uterine fibroids and prostate tumors (8-10). Ultrasound has also been used extensively in medical diagnosis and increasingly for therapeutic purposes as it has been applied in lithotripsy to destroy kidney stones and as a surgical tool to remove tumor tissue and as a tool for drug delivery (11). Ultrasound has been used in imaging and revolutionized the treatment of cystic, echinococcosis, and ultrasound is preferred because it is a non-invasive technique and because of the stages of development of the cysts, in detail, as well as its ability to indicate the sites of the, cysts, their number, size and stages of development, also to guide the treatment through the skin $(12,13)$. Eradication by High intensity focused ultrasound has shown efficacy in uncomplicated 
cases for patients with alveolar cyst disease in the liver, as it has shown efficacy in protoscoleces and laminar component of the lamellar and germinal layers of cystic larvae of alveolar parasites causing the death of morphogenic cells that are responsible for necrosis liver biopsy results after eradication confirmed the destructive effect of protoscoleces and cellular components in the germinal layer of alveolar cysts in the larval stages. Highintensity ultrasound is a promising treatment for alveolar echinococcosis (10).

The aim of the study is to demonstrate the influence of ultrasound on the cell-mediated immunity represented by delayed type hypersensitivity in mice infested with secondary cystic echinococcosis.

\section{Materials and methods}

\section{Echinococcosis protoscoleces isolation}

Protoscoleces were obtained and isolated from hydatid cysts in the livers of infected sheep in Mosul city according to Smyth (14). The hydatid cysts were sterilized by alcoholic iodine $1 \%$, hydatid cyst fluid was withdrawn by $10 \mathrm{ml}$ medical syringe, washed, the cyst fluid with protoscoleces were washed by Phosphate Buffer Saline PBS pH 7.2 and centrifuged $3000 \mathrm{r} / \mathrm{m}$ three times, with the addition of Penicillin $2000 \mathrm{IU}$ and Streptomycin $1 \mathrm{gm} / \mathrm{L}$ during the second stage centrifugation, after the third stage the supernatant was withdrawn, PBS was added to the sterilized protoscoleces sediment, viability was estimated by adding $20 \mu \mathrm{l}$ of eosin $0.1 \%$ to the same size of protoscoleces on the slide, then tested for viability by light microscope, for $100 \%$ fertility, the light green protoscoleces with flame cells are viable, the red ones are dead (14).

\section{Exposure to ultrasound}

Ultrasound machine type (omni, United Kingdom) was used for exposure all the samples to same frequency 20000 pulse $\left(1.8 \mathrm{w} / \mathrm{cm}^{2}\right)$. To determine the effect of ultrasound on the vitality of protoscoleces in vitro, 2000 protoscoleces $/ \mathrm{ml}$ of $100 \%$ vitality were put in the ultrasound device, with the ice around the sample, the samples were exposed for 30, 20, $15,12,10,5$ second, the post exposure vitality was 0,17 , $34,50,80,90 \%$ respectively.

\section{Mice inoculation}

A total of Thirty-five male swiss mice type Mus musculus $\mathrm{BBALB} / \mathrm{c}$ were used in the present study. All the mice were placed in suitable laboratory conditions at a temperature $25 \pm 2$, they were divided into 7 groups ( 5 mice per group), six groups were injected with protoscoleces exposed to ultrasound waves, while the seventh group was injected with non-exposed protoscoleces as a control group. Groups from 1-7 were injected with 2000 protoscoleces of different vitality $0,17,34,50,10,90,100 \%$ respectively.

\section{Antigen preparation and injection}

Antigen of protoscoleces was prepared as described (15), and the antigen protein was assessed as described (16). Delayed type hypersensitivity was measured according to Ali Khan (17), as following: $1 \mathrm{ml}$ of the antigen (143 microgram) was injected into the right footpad of the mouse, the left footpad was injected with the same volume of Phosphate buffer saline PBS, the thickness of the foot pad was measured by Vernier after 3, 24, 48 hour after antigen injection.

The difference between the readings represents delayed type hypersensitivity. Each group was injected once with the antigen at the end of each experiment, 2, 3, 4, 5 months post infection. Delayed type hypersensitivity was assessed in all groups during the period: 2, 3, 4, 5 months post infection with exposed protoscoleces, in addition to the control not exposed group.

\section{Statistical analysis}

All the data were analyzed according to Complete Randomized Analysis, to explain the effects of durations and exposures, the differences between the averages of each factor and the compatibility between the two factors levels were tested by Duncan's multiple test, Statistical Analysis System (SAS version 9) was applied for data analysis and tests (18).

\section{Results}

From the results ultrasound has significant effect on the protoscoleces which represented by the thickness of the foot pad after $3 \mathrm{~h}, 24 \mathrm{~h}, 48 \mathrm{~h}$ post antigen injection in mice infected with exposed protoscoleces compared with control group (Table 1).

Multiple-range test revealed significant differences in six treated groups recorded highest footpad thickness after $3 \mathrm{~h}$ post antigen injection, $1.54 \mathrm{~mm}$ at $20 \mathrm{~s}$ exposure, followed by $1.5 \mathrm{~mm}$ at $30 \mathrm{~s}, 1.31 \mathrm{~mm}$ at $15 \mathrm{~s}, 1.22 \mathrm{~mm}$ at $5 \mathrm{~s}$, $1.2 \mathrm{~mm}$ at $12 \mathrm{~s}$ and $1.18 \mathrm{~mm}$ at $10 \mathrm{~s}$, after five months of infection, compared with the control group $1.072 \mathrm{~mm}$ (Table 2).

Duncan's multiple-range test revealed significant differences in all treated mice after $24 \mathrm{~h}$ post antigen injection. The highest thickness of the foot pad was $1.4 \mathrm{~mm}$ at 10s exposure for five months' post infection, followed by $1.106 \mathrm{~mm}$ at $5 \mathrm{~s}, 1.054 \mathrm{~mm}$ at $15 \mathrm{~s}, 1.034 \mathrm{~mm}$ at $12 \mathrm{~s}, 1.02$ $\mathrm{mm}$ at $30 \mathrm{~s}, 0.964 \mathrm{~mm}$, respectively, in comparison with control group $0.638 \mathrm{~mm}$ (Table 3).

Result showed significant differences in experimental exposed animals, the highest foot pad thickness was 0.9 $\mathrm{mm}$ at $10 \mathrm{~s}$, followed by $0.83 \mathrm{~mm}$ at $5 \mathrm{~s}, 0.68 \mathrm{~mm}$ at $30 \mathrm{~s}$, $0.6334 \mathrm{~mm}$ at $12 \mathrm{~s}, 0.604 \mathrm{~mm}$ at $20 \mathrm{~s}$, and $0.524 \mathrm{~mm}$ at $15 \mathrm{~s}$, respectively, after five months of injury, when compared with the control group $0.328 \mathrm{~mm}$ (Table 4). 
Iraqi Journal of Veterinary Sciences, Vol. 35, Supplement I, 2021 (1-5)

Proceedings of the 2nd Scientific Conference, College of Veterinary Medicine, University of Duhok

Table 1: Statistic of the footpad thickness after $3 \mathrm{~h}, 24 \mathrm{~h}$ and $48 \mathrm{~h}$ post antigen injection in mice injected with protoscoleces

\begin{tabular}{lcccccccccc}
\hline \multirow{2}{*}{ Degrees of difference } & \multirow{2}{*}{ df } & \multicolumn{3}{c}{ 3h } & \multicolumn{3}{c}{ 24h } & \multicolumn{3}{c}{ 48h } \\
\cline { 3 - 11 } & & Sum & Average & F & Sum & Average & F & Sum & Average & F \\
\hline Periods & 3 & 0.73603643 & $0.2453^{* *}$ & 4.48 & 1.3173 & $0.4391^{* *}$ & 9.33 & 1.7737 & $0.5912^{* *}$ & 27.66 \\
Treatment & 6 & 1.08434 & $0.1807^{* *}$ & 3.30 & 1.31336 & $0.2188^{* *}$ & 4.65 & 0.7060 & $0.1176^{* *}$ & 5.50 \\
Periods x treatment & 18 & 0.94224857 & 0.0523 & 0.96 & 1.3357 & 0.0742 & 1.58 & 0.9516 & $0.0528^{* *}$ & 2.47 \\
Experimental error & 112 & 6.12976 & 0.0547 & & 5.2709 & 0.0470 & & 2.3943 & 0.0213 & \\
\hline
\end{tabular}

*significant of $\mathrm{P} \leq 0.01 * *$ significant of $\mathrm{P} \leq 0.05$.

Table 2: Footpad thickness 3 hours post antigen injection in mice injected with protoscoleces exposed to ultrasound

\begin{tabular}{lccccc}
\hline Exposure & 2 & 3 & 4 & 5 & Average treatment \\
\hline Control & $1.096^{\mathrm{de}}$ & $1.062^{\mathrm{de}}$ & $1.07^{\mathrm{de}}$ & $1.072^{\mathrm{de}}$ & $1.075^{\mathrm{c}}$ \\
$30 \mathrm{~s}$ & $1.34^{\mathrm{abcd}}$ & $1.178^{\mathrm{bcde}}$ & $1.37^{\mathrm{abcd}}$ & $1.5^{\mathrm{ab}}$ & $1.347^{\mathrm{a}}$ \\
$20 \mathrm{~s}$ & $1.32^{\mathrm{abcd}}$ & $1.154^{\mathrm{bcd}}$ & $1.258^{\mathrm{abcde}}$ & $1.54^{\mathrm{a}}$ & $1.318^{\mathrm{a}}$ \\
$15 \mathrm{~s}$ & $1.204^{\mathrm{abcde}}$ & $1.222^{\mathrm{abcde}}$ & $1.162^{\mathrm{bcde}}$ & $1.31^{\mathrm{abcd}}$ & $1.2245^{\mathrm{abc}}$ \\
$12 \mathrm{~s}$ & $1.372^{\mathrm{abcd}}$ & $1.132^{\mathrm{cde}}$ & $1.13^{\mathrm{cde}}$ & $1.2^{\mathrm{abcde}}$ & $1.2085^{\mathrm{abc}}$ \\
$10 \mathrm{~s}$ & $1.294^{\mathrm{abcde}}$ & $1.14^{\mathrm{bcde}}$ & $0.94^{\mathrm{e}}$ & $1.18^{\mathrm{abcde}}$ & $1.14^{\mathrm{bc}}$ \\
$5 \mathrm{~s}$ & $1.486^{\mathrm{abc}}$ & $1.22^{\mathrm{abcde}}$ & $1.08^{\mathrm{de}}$ & $1.22^{\mathrm{abcde}}$ & $1.2515^{\mathrm{ab}}$ \\
\hline Average & $1.3017^{\mathrm{a}}$ & $1.5829^{\mathrm{b}}$ & $1.14429^{\mathrm{b}}$ & $1.28971^{\mathrm{a}}$ & \\
\hline
\end{tabular}

Identical letters were not considerable variation. Diverse letters were considerable variation.

Table 3: Footpad thickness 24-hour post antigen injection in mice injected with protoscoleces

\begin{tabular}{lccccc}
\hline Exposure & 2 & 3 & 4 & 5 & Average treatment \\
\hline Control & $0.878^{\text {nbcdefg }}$ & $0.676^{\mathrm{fg}}$ & $0.614^{\mathrm{g}}$ & $0.638^{\mathrm{fg}}$ & $0.7015^{\mathrm{b}}$ \\
$30 \mathrm{~s}$ & $0.84^{\text {bcdefg }}$ & $0.902^{\text {bcdefg }}$ & $1.1^{\mathrm{b}}$ & $1.02^{\mathrm{bcde}}$ & $0.9655^{\mathrm{a}}$ \\
$20 \mathrm{~s}$ & $0.866^{\mathrm{bcdefg}}$ & $0.76^{\mathrm{cdefg}}$ & $1.08^{\mathrm{bc}}$ & $0.964^{\mathrm{bcdef}}$ & $0.9175^{\mathrm{a}}$ \\
$15 \mathrm{~s}$ & $0.952^{\text {bcdef }}$ & $0.808^{\mathrm{bcdefg}}$ & $1.102^{\mathrm{b}}$ & $1.054^{\mathrm{bcd}}$ & $0.979^{\mathrm{a}}$ \\
$12 \mathrm{~s}$ & $0.979^{\mathrm{a}}$ & $0.87^{\mathrm{bcdefg}}$ & $1.032^{\mathrm{bcde}}$ & $1.034^{\mathrm{bcde}}$ & $0.962^{\mathrm{a}}$ \\
$10 \mathrm{~s}$ & $0.934^{\mathrm{bcdfg}}$ & $0.716^{\mathrm{efg}}$ & $1.04^{\mathrm{bcde}}$ & $1.4^{\mathrm{a}}$ & $1.0225^{\mathrm{a}}$ \\
$5 \mathrm{~s}$ & $0.906^{\text {bcdefg }}$ & $0.74^{\text {defg }}$ & $1.012^{\mathrm{bcde}}$ & $1.106^{\mathrm{b}}$ & $0.941^{\mathrm{a}}$ \\
\hline Average & $0.89829^{\mathrm{b}}$ & $0.78171^{\mathrm{c}}$ & $0.99714^{\mathrm{ab}}$ & $1.03086^{\mathrm{a}}$ & \\
\hline
\end{tabular}

Identical letters were not considerable variation. Diverse letters were considerable variation.

Table 4: Footpad thickness 48-hour post antigen injection in mice injected with protoscoleces

\begin{tabular}{lccccc}
\hline Exposure & 2 & 3 & 4 & 5 & Average treatment \\
\hline Control & $0.328^{\text {hij }}$ & $0.296^{\mathrm{j}}$ & $0.312^{\mathrm{ij}}$ & $0.328^{\text {hij }}$ & $0.329^{\mathrm{c}}$ \\
$30 \mathrm{~s}$ & $0.44^{\text {defghij }}$ & $0.276^{\mathrm{j}}$ & $0.406^{\text {efghij }}$ & $0.68^{\mathrm{bc}}$ & $0.4505^{\mathrm{b}}$ \\
$20 \mathrm{~s}$ & $0.424^{\text {defghij }}$ & $0.444^{\text {defghij }}$ & $0.39^{\text {efghji }}$ & $0.604^{\text {cde }}$ & $0.4655^{\mathrm{b}}$ \\
$15 \mathrm{~s}$ & $0.602^{\text {cdef }}$ & $0.296^{\mathrm{j}}$ & $0.546^{\text {cdefgh }}$ & $0.524^{\text {cdefghi }}$ & $0.492^{\mathrm{ab}}$ \\
$12 \mathrm{~s}$ & $0.382^{\text {efghij }}$ & $0.342^{\text {ghij }}$ & $0.5^{\text {cdefghij }}$ & $0.6334^{\text {cd }}$ & $0.46435^{\mathrm{b}}$ \\
$10 \mathrm{~s}$ & $0.53^{\text {cdefghi }}$ & $0.352^{\text {ghi }}$ & $0.53^{\text {cdefghi }}$ & $0.9^{\mathrm{a}}$ & $0.578^{\mathrm{a}}$ \\
$5 \mathrm{~s}$ & $0.428^{\text {defghij }}$ & $0.28^{\mathrm{j}}$ & $0.556^{\text {cdefg }}$ & $0.83^{\mathrm{ab}}$ & $0.5235^{\mathrm{ab}}$ \\
\hline Average & $0.45514 \mathrm{~b}$ & $0.32657^{\mathrm{c}}$ & $0.46286^{\mathrm{b}}$ & $0.64277^{\mathrm{a}}$ & \\
\hline
\end{tabular}

Identical letters were not considerable variation. Diverse letters were considerable variation.

\section{Discussion}

Delayed-type hypersensitivity (DTH) is a T-cell mediated inflammatory response in which the stimulation of antigen-specific effector $\mathrm{T}$ cells leads to macrophage activation and localized inflammation and edema within tissues. This effector $\mathrm{T}$ cell response is a normal component of adaptive immunity, and essential for the control of intracellular and other pathogens. Subsequent exposure of the sensitized individual to the exogenous antigen, either 
injected intradermal or applied to the epidermis, results in the recruitment of antigen specific $\mathrm{T}$ cells to the site and the development of local inflammatory response over 24-72 hours (19).

If the foreign antigen persists in the tissues, chronic activation of $\mathrm{T}$ cells and macrophages may lead to granuloma formation and tissue damage. IV hypersensitivity reflects the presence of antigen specific $\mathrm{CD} 4 \mathrm{~T}$ cells and is associated with protective immunity against intracellular and other pathogens. According to the Coombs and Gell classification, type IV or DTH reactions take more than 12 hours to develop and involve cellmediated immune reactions rather than antibody responses to antigen. Some other hypersensitivity reactions may straddle this definition with a rapid-antibody-mediated phase, and a later cell-mediated phase. For example, the phase IgE-mediated reaction may peak 12-24 hours after contract with an allergen, and cells such as helper T (TH2) cells and eosinophils, contribute of the inflammation as well as $\operatorname{IgE}(20)$.

The results of the cell-mediated immunity appeared by DTH of foot pad in the mice showed an increase in the thickness of the footpad thickness for $3 \mathrm{~h}$ after injection in animals injected with exposed protoscoleces compared to unexposed mice and began to decline $24 \mathrm{~h}$ and continued to decrease $48 \mathrm{~h}$ after insertion by the antigen, the increased thickness of the footpad is referred to the capability of ultrasound to induce cell mediated immunity, which is represented by swelling of the footpad, this result is in agreement with Ali and Khethr (21), when studied the effect of ultrasound on the cell-mediated immunity in rats inoculated with cysts of Giardia lamblia, and explained the significant differences between treated and non-treated rats.

The most distinctive feature of delayed-type hypersensitivity reactions is the increase of T-helper cells $\mathrm{TH} 2$ in tissues followed by increase in eosinophils. These reactions induce secretion of chemicals stimulant for the bounding with the epithelial cells that are significant for eosinophils migration. This indicates the vital role of $\mathrm{TH} 2$ and INF-y in hypersensitivity reactions (20). The swelling produced from these reactions is referred to infiltration of macrophages, neutrophils, lymphocytes and monocytes during the histological test of the footpad. Previous studies explained that the cause of hypersensitivity is the stimulation of T-lymphocytes to produce cytokines, which in turn mediate a group of inflammatory reactions $(19,20)$. Yassen (22), Ali and Salim (23) were used protoscoleces of Echinococcus granulosus exposed to electric current, and they found significant differences between treated and nontreated mice. Furthermore, Ali and Mohammed (24) tested the effect of Laser radiation on the cellular immunity in mice infected with hydatidosis, and found that the laser radiation boosted delayed-type hypersensitivity in treated animals.
Cell Mediated Immunity represented by swelling of the foot pad resulting in edema and a series of inflammations due to $\mathrm{T}$ helper cells that are responsible for cellular immune responses, which is the result of cytokines secreted from mononuclear cells, especially phagocytic and $\mathrm{T}$ cells, which were activated when antigen injected. Over time, depletion of $\mathrm{T}$ cells occurs, and this is associated with a decrease in the thickness of the foot pad. Because of reduced antigen stimulation of lymphocyte transformation in treated mice (25).

\section{Conclusion}

It may well be concluded that ultrasound may play a significant role on specific cellular immunity represented by delayed-type hypersensitivity in mice infected with hydatid disease, and may be used as a future alternative therapy for treatment of hydatidosis.

\section{Acknowledgement}

We would like to acknowledge University of Mosul, Education College for Pure Science, Faculty of Science, for support this research.

\section{Conflict of interest}

The authors declare no conflicts of interest.

\section{References}

1. Wang H, Li Z, Gao F, Zhao J, Zhu M, He X, Niu N, Zhao W. Immunoprotection of recombinant Eg P29 against Echinococcus granulosus in sheep. Vet Res Coumm. 2016;40(2):73-79. DOI: 10.1007/s11259-016-9656-7

2. Khanbabaie S, Riazi M, Chang CH, Yunus MH, Noordin R. Lateral flow dipstick antigen assay for human cystic echinococcosis. Acta tropica. 2019;190:171-176. DOI: 10.1016/j.actatropica.2018.11.018

3. Hasona, NA, Amer OH, Morsi, A, Raef, A. Comparative biochemical, parasitological, and histopathological studies on cystic echinococcosis in infected sheep. Comp Clin Pathol. 2017;26(4):805-810. DOI: 10.1007/s00580-017-2450-2

4. Issa HS, Abdel-Hafez SK, Hijjawi NS, Al-Qaoud KM. Molecular characterization of Echinococcus granulosus sensu stricto cysts of domestic ruminants in Jordan. Jordan J Biol Sci. 2018;11(3):1-3. [available at]

5. Al-lahaibi, BY, Hasan MH, Altaee, AF. Incidence of internal parasites of the slaughtered local breeds of ducks and geese. Iraqi J Vet Sci. 2021;35(1):39-44. DOI: $10.33899 /$ ijvs.2020.126242.1272

6. Díaz Á. Immunology of cystic echinococcosis (hydatid disease). Brit Med Bull. 2017;1-13. DOI: $10.1093 / \mathrm{bmb} / \mathrm{ldx} 033$

7. Yousif, SY, Ali, AA. Effect of probiotic acidophilus plus against infection with secondary hydatid disease in BALB/c mice. Iraqi J Vet Sci. 2020;34(1), 115-121. DOI: 10.33899/ijvs.2019.125613.1104

8. Zhampeissov N, Manap E, Rustemova K, Fedotovskikh, G, Tuganbekov T, Imankulov S, Gaipov A. High-intensity focused ultrasound ablation: A non-surgical approach to treat advanced and complicated liver alveococcosis. J Med Ultrasonics. 2019;46(2):251255. DOI: $\underline{10.1007 / \mathrm{s} 10396-018-0914-\mathrm{x}}$ 
9. She WH, Cheung TT, Jenkins CR, Irwin MG. Clinical applications of high-intensity focused ultrasound. Hong Kong Med J. 2016;22(4):382-392. DOI: 10.12809/hkmj154755

10. Yudina A, Moonen C. Ultrasound-induced cell permeabilization and hyperthermia: istrategies for local delivery of compounds with intracellular mode of action. Inter J Hyperthermia. 2012;28(4):311319. DOI: $10.3109 / 02656736.2012 .664307$

11. Izadifar Z, Babyn P, Chapman D. Mechanical and biological effects of ultrasound: A review of present knowledge. Ultrasound Med Biol. 2017;43(6):1085-1104. DOI: 10.1016/j.ultrasmedbio.2017.01.023

12. Brunetti E, Tamarozzi F, Macpherson C, Filice C, Piontek MS, Kabaalioglu A, Dietrich CF. Ultrasound and cystic echinococcosis. Ultrasound Inter Open. 2018;4(03):E70-E78. DOI: 10.1055/a-0650-3807

13. Ramdan BB, Ali AA. Application of ultrasound contra infection with secondary hydatidosis in mice. Iraqi J Vet Sci. (2020);34(2), 397- 403. DOI: 10.33899 /ijvs.2019.126132.1240

14. Macpherson, CNL, Smyth JD. In vitro culture of the strobilar stage of Echinococcus granulosus from protoscoleces of human, camel, cattle, sheep and goat origin from Kenya and buffalo origin from India. International journal for parasitology. 1985;15(2):137-140. DOI: $10.1016 / 0020-7519(85) 90078-5$

15. Dottorini S, Sparvoli M, Bellucci C, Magnini M. Echinococcus granulosus: Diagnosis of hydatid disease in man. Annal Trop Med Parasitol. 1985;79(1):43-49. DOI: 10.1080/00034983.1985.11811887

16. Schacterle GR, Pollack RL. A simplified method for the quantitative assay of small amounts of protein in biologic material. Analyt Biochem. 1973;51(2):654-655. DOI: 10.1016/0003-2697(73)90523-X

17. Ali-Khan Z. Echinococcus multilocularis: Cell-mediated immune response in early and chronic alveolar murine hydatidosis. Experiment Parasitol. 1978;46(2):157-165. DOI: 10.1016/0014-4894(78)90128-5

18. Seo S, Jeon S, Ha JK. Guidelines for experimental design and statistical analyses in animal studies. Asian-Aust JAnim Sci. 2018;31(9):1381-1386. DOI: 10.5713/ajas.18.0468

19. Male D, Brostoff J, Roth DB, Roitt I. Immunology. $8^{\text {th }}$ ed. USA: Mosby Elsevier Ltd; 2012. 477 p.

20. Willey JM, Sherwood L, Woolverton CJ. Prescott H. Klein's Microbiology. $7^{\text {th }}$ ed. USA: McGraw-Hill Companies; 2008. 782-788 p.

21. Ali AA, Khethr HM. Immune response improvement against giardiasis in male albino rats by using ultrasound. Rafidain J Sci. 2018;27(4):388-401. DOI: $10.33899 /$ rjs.2018.159369

22. Yaseen SS. The Effect of Protoscoleces treated with direct electrical current on the cellular immune response in mice infected with secondary hydatid disease. J Edu Sci. 2010;23:15-23. DOI. 10.33899/edusj.2010.57985

23. Ali AA, Salim F. Effect of Direct Electrical Current on Protoscoleces of Echinococcus granulosus in vitro and on Immune Response of BALB/c Mice Against Infection with Secondary Hydatid Disease. Eurasia Proceed Sci Technol Eng Mathemat. 2018;1(3):90102. [available at]
24. Ali AA, Mohammed ZD. Effect of laser radiation on the immune response of mice against infection with secondary hydatid disease. I. Growth and development of hydatid cysts. J Edu Sci. 2018;27(3):6680. DOI: $10.33899 /$ edusj.2018.159319

25. Ryu HI, Kim CJ. Immunologic reactivity of a lipopolysaccharideprotein complex of type A Pasteurella multocida in mice. J Vet Sci. 2000;1(2):87-95. [available at]

\section{ثأثيز الموجات فوق الصوثية على الرؤيسات

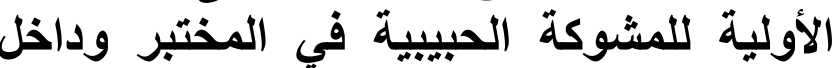 | (لحس \\ أسماء عبد العزيز علي و براء باسل رمضان}

قسم علوم الحياة، كلية التربية للعلوم الصرفة، جامعة الموصل، الموصل، العراق

الخلاصة

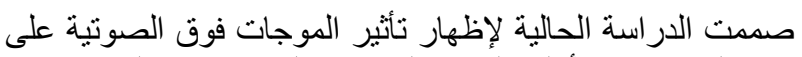

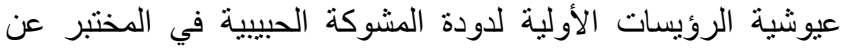

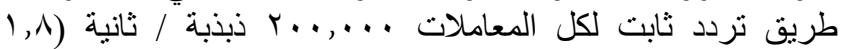

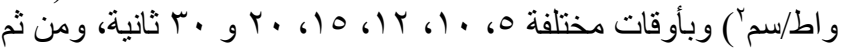

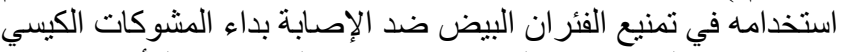

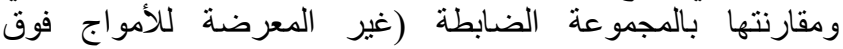

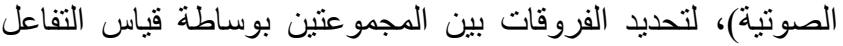
المناعي المكتسب (الاستجابة المناعية المتخصصة الخصوفة الخلوية ) المتمثلة

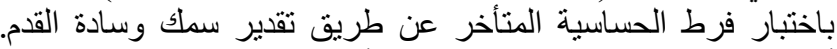

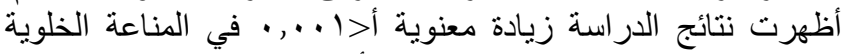

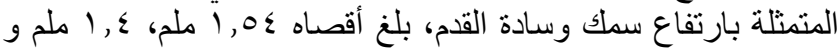

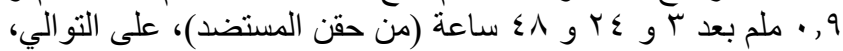

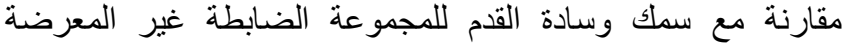

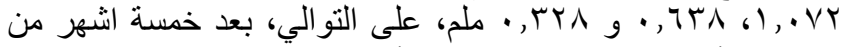

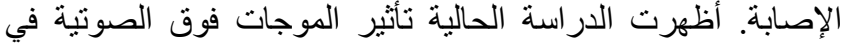
حيوية الرؤيسات الحيوية للمشوكة الحبيبية خارجة الجسم. الإنة الاستنتاج،

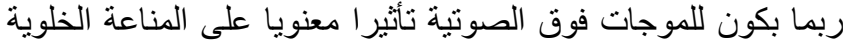

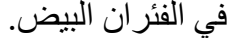

